\title{
A comparative Study on Some Maize Cultivars and Their Relationship to Damage Caused by Hooded Crow, Corvus corone sardonius at Qena Governorate, EGYPT \\ Omar, M.M. Abdel-Aaal
}

Agric. Zoology and Nematology Dept., Fac. of Agric., Al-Azhar Univ. Assiut Branch, Egypt.

E-mail: m_mobarak75@yahoo.com

Received on: $17 / 5 / 2020$

Accepted for publication on: 15/6/2020

\begin{abstract}
Seven field experiments were carried out at Dahsa village, Farshout district, Qena governorate, Egypt, 2019 season to evaluate the damage caused by hooded crow, Corvus corone sardonius on seven cultivars of maize (Zea mays L.). The cultivars were Watania 4, Watania 6, Watania 11, Watania 310, Hytech 2055, Hytech 2066 and Balady. The results revealed that the highest loss was recorded in Balady cultivar (7.17\%), followed by single cross Hytech 2055 and S. C. Hytech 2066 (2.50 and 2.17\%) as yellow seeds of maize. Moderate loss was recorded in three way cross Watania 11 and T. W. Watania $310(1.83$ and $1.33 \%)$ as white seeds of maize. While the lowest loss was recorded in S. C. Watania 6 and S.C. Watania $4(0.17$ and $0.67 \%)$ as white seeds of maize. Generally, the highest loss was recorded in maize cultivars of yellow seeds. While, the lowest loss was recorded in maize cultivars of white seeds. So, the yellow cultivars may be preferable for cultivation than white cultivars maize, besides the high oil in yellow cultivars of maize.
\end{abstract}

Keywords: Hooded crow, damage, white, yellow, seeds, maize, cultivar.

\section{Introduction}

Maize (Zea mays L.) is the third most cereal crop in the world, providing nutrient of humans and animals. The behavior of crows can vary widely from place to place. However, in many places, crows will gather in autumn and winter to spend the night in large communal roosts containing several hundred to many thousand birds. Roosts as large as 200.000 or more birds have been reported. Communal roosts may remain in one location for a number of years or may shift from place in response to changing conditions (Jakimaki and Suhonen, 1998).

The hooded crow, Corvus corone sardonius has described as
Nile valley bird, the head, the throat and neck are generally black, the wings and tail are black. Also, the chest and flanks are gray in color. The bill and legs are black. On the other hand, it the most intelligent species of crow, wary, resourceful and usually stay in pairs (El-Huseiny, 1940). The hooded crow, C. corone sardonius is one of the most important bird residents in Egypt. It is one of the most important agricultural pests in the cultivated areas, such as maize, peanuts, sunflower, (Metwally et al., 1995; Khattab et al., 2002; Bonnah, 2007 and Issa and ElBakhshawngi, 2018). C. corone sardonius, also, has a wide variety of food including maggots and beetles, 
small mammals, frogs, young or wounded birds, some Mollusca, and other invertebrates. Sometimes feeds on vegetable foods and grains (ElHuseiny, 1940).

The present work was done at the Dahsa village, Farshout district, Qena Governorate to estimate the damage caused by hooded crow, Corvus corone sardonius in preharvest of some maize cultivars during 2019 season.

\section{Materials and Methods}

The experiments were conducted in old areas at Dahsa village, Farshout district, Qena governorate, Egypt, during the growing season 2019, to deter the damage caused by the hooded crow, Corvus corone sardonius to some cultivars of maize (Zea mays L.). Seven cultivated fields with maize crop were selected to the damage caused by crows on maize cultivars. The studied genotypes of maize were four white seeds color, two single cross (Watania 4 and Watania 6) and two three way cross (Watania 11 and Watania 310), three Yellow seeds color, two single cross (Hytech 2055 and Hytech 2066) in addition to Balady cultivar.

The experiment was grown in a randomized complete blocks design (R.C.B.D.) with five replications for each cultivar. The experimental plot comprise five ridges of 3.5 meter long with $60 \mathrm{~cm}$. between ridges, sowing was in hills spaced $20 \mathrm{~cm}$. apart, on one side of the ridge with one seed per hill using Afir method of planting. Rows were sown with pathways $50 \mathrm{~cm}$. between blocks of plots for each entry. The recommended practices of maize production were followed throughout the growing season. Data were collected from ten plants of each plot excluding borders as mentioned above for each maize cultivars.

Assessment bird damage was carried out in maize fields during summer season of 2019 after silking stage till the pre-harvest. Thirty successive plants were inspected in each plot to estimate the degree of damage in the investigated ears. Samples were taken weekly and the degree of damage due to crows in the ears was estimated according to Hamelink (1981) by using the following equations:

Damage (\%) $=\frac{0.0 \times \mathrm{S}_{1}+0.25 \times \mathrm{S}_{2}+0.50 \times \mathrm{S}_{3}+0.75 \times \mathrm{S}_{4}+1.0 \times \mathrm{S}_{5}}{\mathrm{~N}} \times 100$

Were:

$\mathrm{S}_{1}=$ No of undamaged ears; $\mathrm{S}_{2}=$ No. of $1 / 4$ damaged ears; $S_{3}=$ No. of $1 / 2$ damaged ears; $\mathrm{S}_{4}=$ No. of $3 / 4$ damaged ears; $\mathrm{S}_{5}=$ No. of complete damaged ears; $\mathrm{N}=$ Total Number of investigated ears. 


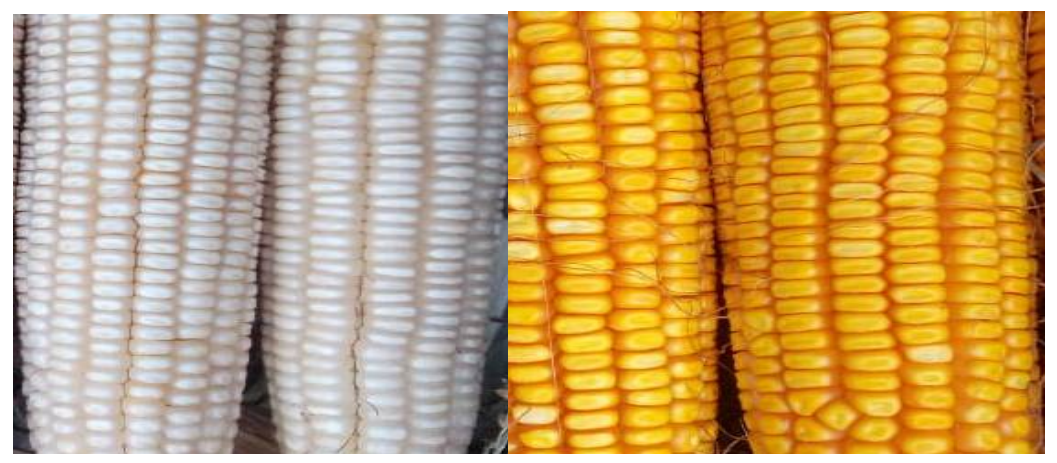

1) White seeds maize.

Data obtained of the damage (\%) were statistically analyzed using a randomized complete block design. Comparison between means of each factor was carried out using Duncan range tests (Duncan, 1955).

\section{Results and Discussion}

\section{Birds damage to maize (Zea mays} L.):

Maize is one of the preferred food items for hooded crow, $C$. corone sardonius. The crows attacked maize during developing maize ears immediately following pollination and during the early stages of grain filling. It caused a great amount of damage to ears and this can lead to missing or damaged kemels on these ears, induced big losses and poor grain quality. Damage is usually concentrated along field edges, but also it can involve entire fields.

a) White of maize cultivars:

Data presented in Table (1) show the damage caused by hooded crow, C. corone sardonius in genotype single and three cross of maize. The highest loss was
2) Yellow seeds maize.

recorded in the genotype T.W.C. (Watania 11) with mean of $1.83 \%$, followed by genotype T.W.C. (Watania 310) (1.33\%). While the lowest loss was recorded in the genotype S.C. (Watania 6) with mean of $0.17 \%$, followed by genotype S.C. (Watania 4) with mean of $0.67 \%$. The results showed that there were significant differences between T.W.C. (Watania 11) and S. C. (Watania 6 and Watania 4). The means of damage percentage were $(0.80$, $0.20,0.00$ and $0.00 \%$ ) recorded at the different degrees of damage 25 , 50,75 and $100 \%$, respectively. Abd el-Hafez et al., (1994) indicated that the damage caused by $C$. corone sardonius to corn fields in Upper Egypt. And they found that attacked corn ears one months before harvest and the damage was clear on ear tops in circles moving downward. 
Table 1. Average percentage of damage caused by hooded crow, Corvus corone sardonius in genotype S.C. and genotype T.W.C. of white maize.

\begin{tabular}{|l|c|c|c|c|}
\hline \multirow{2}{*}{$\begin{array}{c}\text { Percent of ear. } \\
\text { Damage }\end{array}$} & \multicolumn{4}{c|}{ Cultivars of white maize } \\
\cline { 2 - 5 } & \multicolumn{2}{|c|}{ Single cross } & \multicolumn{2}{c|}{ Three way cross } \\
\cline { 2 - 5 } & Watania 4 & Watania 6 & Watania 11 & Watania 310 \\
\hline $25 \%$ damage & 0.80 & 0.20 & 1.00 & 1.20 \\
\hline $50 \%$ damage & 0.00 & 0.00 & 0.60 & 0.20 \\
\hline $75 \%$ damage & 0.00 & 0.00 & 0.00 & 0.00 \\
\hline $100 \%$ damage & 0.00 & 0.00 & 0.00 & 0.00 \\
\hline No damage & 29.20 & 29.80 & 28.40 & 28.60 \\
\hline \% of damage & $0.67 \mathrm{bc}$ & $0.17 \mathrm{c}$ & $1.83 \mathrm{a}$ & $1.33 \mathrm{ab}$ \\
\hline
\end{tabular}

* Means have the same letters are not significantly differed by using Duncan's analysis.

b) Yellow of maize cultivars:

Data in Table (2) revealed that the highest damage was recorded in Balady cultivar with mean of $7.17 \%$, while the lowest loss was recorded in the genotype S.C. (Hytech 2066) with mean of $2.17 \%$, followed by genotype S.C. (Hytech 2055) with mean of $2.50 \%$. The statistical analysis showed that there were high significant differences between the Balady cultivar and other cultivars (Hytech 2055 and Hytech 2066). The means of damage percentage were $(2.20,0.87,0.27$ and $0.00 \%)$ recorded in the different degrees of damage 25 , 50,75 and $100 \%$, respectively. Khattab et al., (2002) revealed that hooded crow, C. corone sardonius attack the maturing stage of Zea maize, the preferred time from 35 to 42 days after silking with values 13.21 and $13.90 \%$ in ear without pruning and 19.61 and $20.89 \%$ in those with pruning.

Table 2. Average percentage of damage caused by hooded crow, Corvus corone sardonius in genotype $S$. C. of yellow maize.

\begin{tabular}{|l|c|c|c|}
\hline \multirow{2}{*}{\begin{tabular}{c}
\multirow{2}{*}{$\begin{array}{c}\text { Percent of ear } \\
\text { damage }\end{array}$} \\
\cline { 2 - 3 }
\end{tabular}} & \multicolumn{3}{c|}{ Cultivars of yellow maize } \\
\cline { 2 - 3 } & Hytech 2055 & Hytech 2066 & \multirow{2}{*}{ Balady } \\
\hline $25 \%$ damage & 1.80 & 1.80 & 3.00 \\
\hline $50 \%$ damage & 0.60 & 0.40 & 1.60 \\
\hline $75 \%$ damage & 0.00 & 0.00 & 0.80 \\
\hline $100 \%$ damage & 0.00 & 0.00 & 0.00 \\
\hline No damage & 27.60 & 27.80 & 24.60 \\
\hline$\%$ of damage & $2.50 \mathrm{~b}$ & $2.17 \mathrm{~b}$ & $7.17 \mathrm{a}$ \\
\hline
\end{tabular}

* Means have the same letters are not significantly differed by using Duncan's analysis.

Generally, from data in Tables (1 and 2) it revealed that the Balady cultivar exhibited the high loss caused by hooded crow, C. corone sardonius as compared with the other cultivars of maize. This may be due to maturating early (80: 90 days) than the other cultivars of maize $(110: 120$ days). The genotypes S.C. (Watania 6 and Watania 4 cultivars) gave low loss of maize (0.17 and $0.67 \%)$, respectively. Eman - Abdelrazek (2013) reported that the percentage of maize ear damage by, $C$. corone 
sardonius at maturity stage may reach $3.01 \%$ up to $3.06 \%$.

Data in Table (3) showed the percentage of damage in the genotype S.C. and genotype T.W.C. of white maize. The highest crows loss was recorded in genotype T.W.C. with mean of $1.58 \%$ as compared with the genotype S.C. $(0.83 \%)$ for white maize. This difference of birds damage may be due mainly to the variation in morphology and phonology characteristics of maize seeds. Abdel-Haleem et al., (2006) reported that the plant height and ear height of the cross T.W.C. 324 gave high average with high degree of stability. For ear diameter all the tested genotypes except T.W.C. 321 and T.W.C. 322 gave high average of ear diameter with high degree of stability. All the crosses except S.C.123 gave high average of ear length with high degree of stability and genotype T.W.C. 324 was top of those genotypes.

Table 3. Average percentage of damage caused by hooded crow, Corvus corone sardonius in genotype S.C. and genotype T.W.C. of white maize.

\begin{tabular}{|l|c|c|}
\hline \multirow{2}{*}{ Percent of ear damage } & \multicolumn{2}{|c|}{ Cultivars of White Maize } \\
\cline { 2 - 3 } & Single cross & Three way cross \\
\hline $25 \%$ damage & 0.60 & 1.10 \\
\hline $50 \%$ damage & 0.20 & 0.40 \\
\hline $75 \%$ damage & 0.00 & 0.00 \\
\hline $100 \%$ damage & 0.00 & 0.00 \\
\hline No damage & 29.20 & 28.50 \\
\hline \% of damage & $0.83 \mathrm{~b}$ & $1.58 \mathrm{a}$ \\
\hline
\end{tabular}

* Means have the same letters are not significantly differed by using Duncan's analysis.

In addition, data in Table (4) showed that the genotype S.C. of white and yellow maize. The highest loss was recorded in genotype S.C. of yellow maize $(2.33 \%)$, while, the lowest loss was recorded in genotype S.C. of white maize with mean of
$0.83 \%$. This may be to the high percent of oil in seeds of yellow maize cultivars than that of the white maize cultivars. Bonnah (2007) found that the percent of damage caused by hooded crow, $C$. corone sardonius on corn ears was $(6.16 \%)$.

Table 4. Average percentage of damage caused by hooded crow, Corvus corone sardonius in single cross of white and yellow maize under field conditions.

\begin{tabular}{|l|c|c|}
\hline \multirow{2}{*}{ Percent of ear damage } & \multicolumn{2}{|c|}{ Maize cultivars } \\
\cline { 2 - 3 } & White maize & Yellow maize \\
\cline { 2 - 3 } & Single cross & Single cross \\
\hline $25 \%$ damage & 0.60 & 1.80 \\
\hline $50 \%$ damage & 0.20 & 0.50 \\
\hline $75 \%$ damage & 0.00 & 0.00 \\
\hline $100 \%$ damage & 0.00 & 0.00 \\
\hline No damage & 29.20 & 27.70 \\
\hline$\%$ of damage & $0.83 \mathrm{~b}$ & $2.33 \mathrm{a}$ \\
\hline
\end{tabular}

* Means have the same letters are not significantly differed by using Duncan's analysis. 


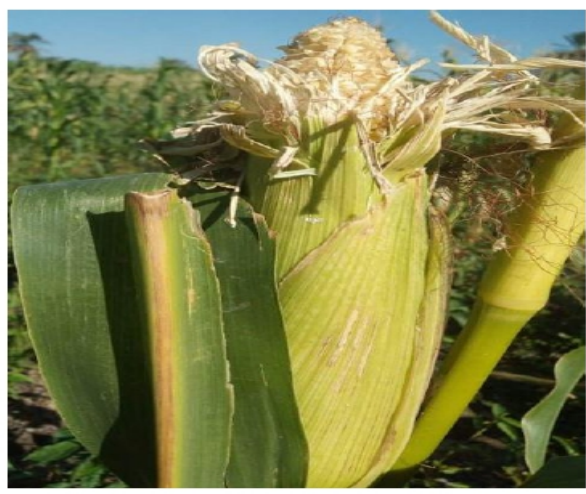

3) $25 \%$ damage.

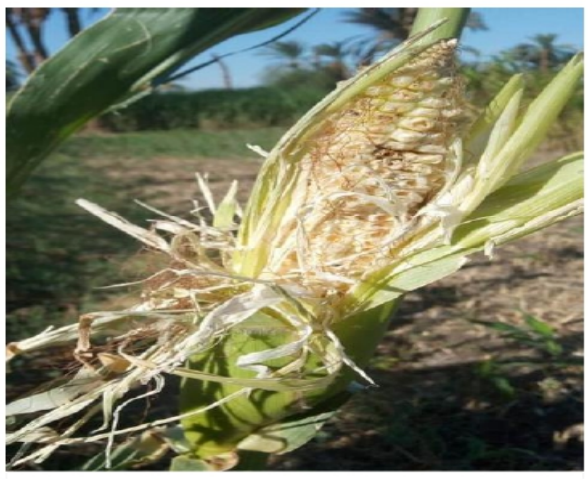

5) $75 \%$ damage.

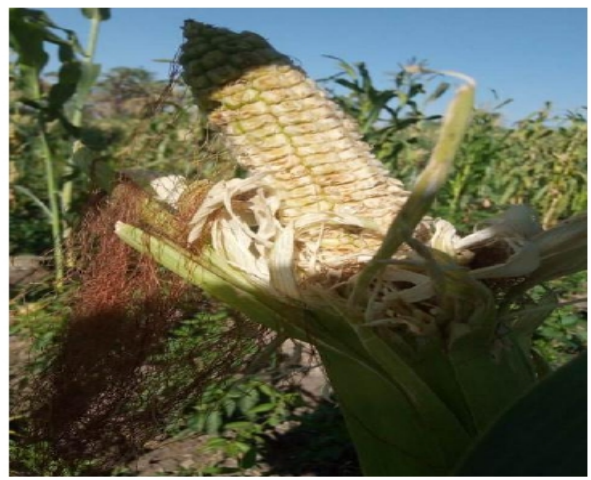

4) $50 \%$ damage.

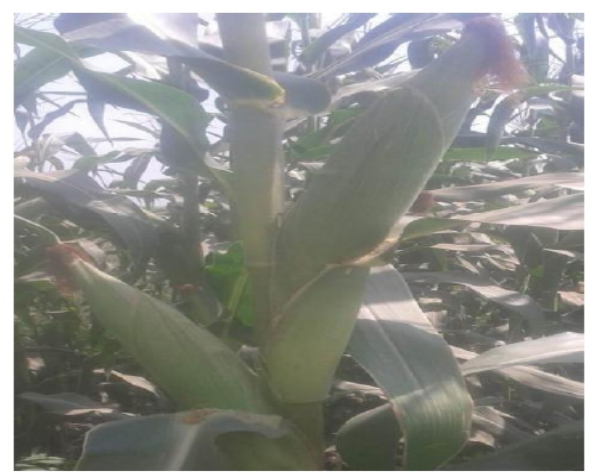

O) Normallv and healthv ears.

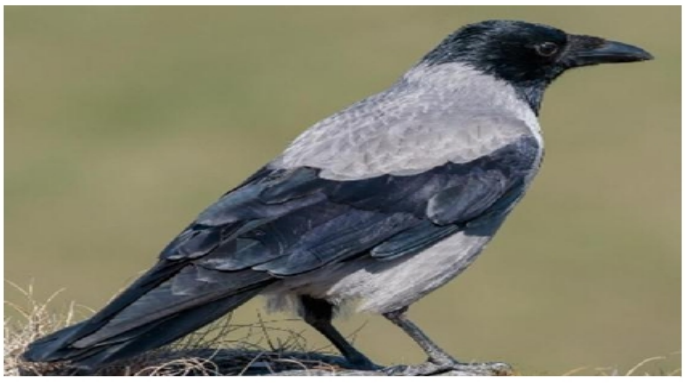

7) Hooded crow, C. conone sardonius

Fig. (3, 4 and 5). Show crows all grains after lifting husks in milky stage of maze ripening.

\section{References}

Abdel- Hafez, A.A.; El-Serbiny, A.H.; Omar, A.M. and Abdel-Moaty, M. E. (1994). Effect of two chemical pesticides in preventing damage caused by the hooded crow, Corvus corone sardonius to corn fields in Upper Egypt. Annal of Agric. Sc. Moshtohor. 32 (1): 595604.
Abdel-Haleem, S.H.M.; El-Beially, I.E. and Mohamed, G.I.A. (2006). Stability parameters of grain yield and its components for some maize genotypes. Al-Azhar J. Agric. Sci. Sector Res. Vol. (1) pp. 45-62.

Bonnah, A.A.M.M. (2007). The damage and control of hooded crow on some plantation in Sohag governorate. Ph.D. Thesis, faculty 
of Agriculture, Assiut University, Egypt, 116.

Duncan's, D.B. (1955). Multiple ranged multiple F-test. Biometrics, 11:147.

El-Huseiny, A. H. (1940). Egyptian birds with summary about their lives. Pp. 119-121.

Eman-Abdelrazek, A.A. (2013). Estimation of maize damage caused by Corvus corone sardonius in Sheben Al-kom Menofia Governorate. Egypt. Acad. J. Biolog. Sei., 4(2): pp. 1117.

Jakimaki, J. and Suhonen, J. (1998). Distribution and habitat selection of wintering birds in urben environments. Landscape and Urban Planning, 39: 253-263.

Hamelink, J. (1981). Assessing rat damage and yield losses in sugar cane, rice and maize. Book of rodent pests and their control. G.T.Z., A.I-III B/5.
Issa, M. A. and El-Bakhshawngi, M. I. A. (2018). An Estimation of bird damages on some field, vegetable and fruit crops at Sharkia governorate, Egypt. Zagazig J. Agric. Res., Vol. 45 No.(4): pp. 1273-1281.

Khattab, M.M., Ismail, Sh. A., Soliman, A.M., and EL-Deeb, H.I., (2002). Damage assessment due to hooded crow, Corvus corone sardonius (Kleinschmidt) at some cultivated plant crops at newly reclaimed fields in Sharkia Governorate. $2^{\text {nd }}$ International Conference, Plant protection Research Institute, Cairo, Egypt.21-24 December 2002: 88-91.

Metwally, A.M.; El - Deeb, H.H. and Abd El - Aal, S.; and Khataab, M.M. (1995). Birds damage to some ripening field crops under different conditions in Sharkia Governorate Al - Azhar J. Agric. Res., $21.413-424$. 
دراسة مقارنة على بعض أصناف الذرة الثامية وعلاقتها بالخسارة المسببة بو اسطة الغزاب

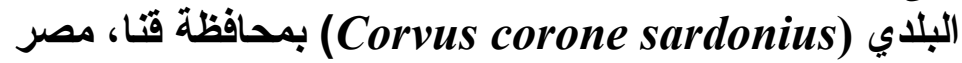

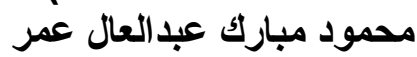

قسم الحيو ان الزر اعى و النيماتودا ـ كلية الزر اعة ـ مجامعة الأز هر فرع أسيوط.

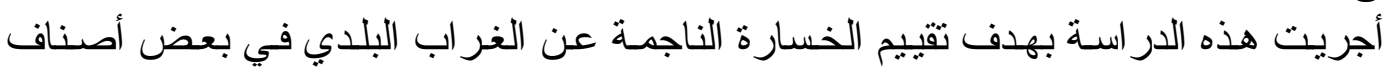

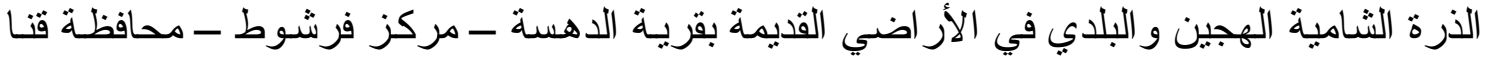

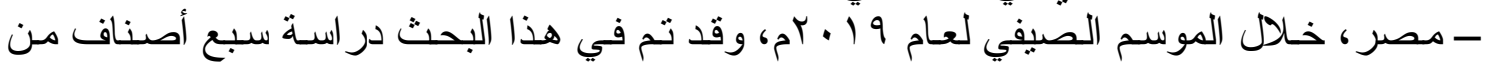

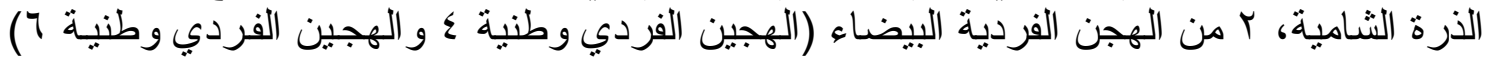

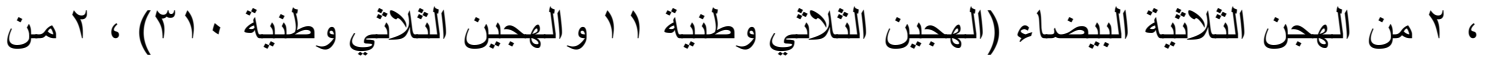

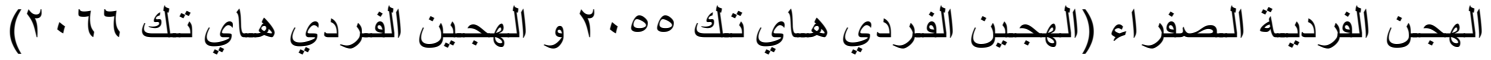

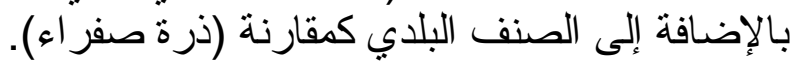
ومن خلال الدر اسة آظهرت النتائج التالية:

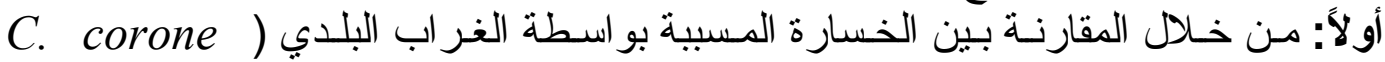
(sardonius

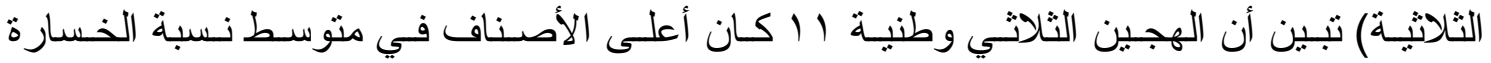

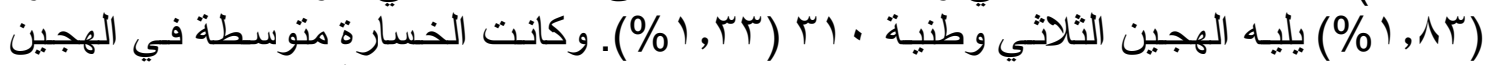

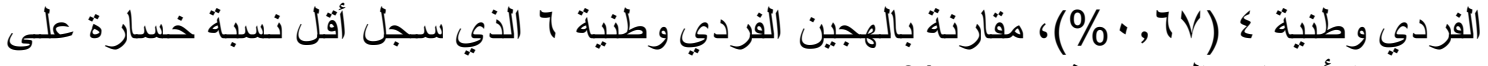

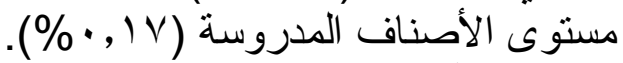

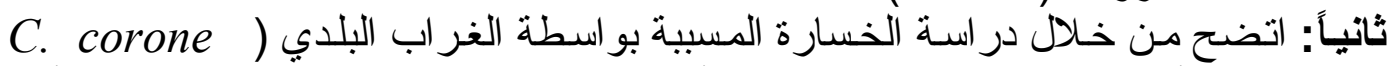

(sardonius

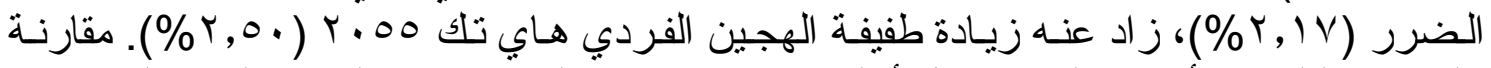

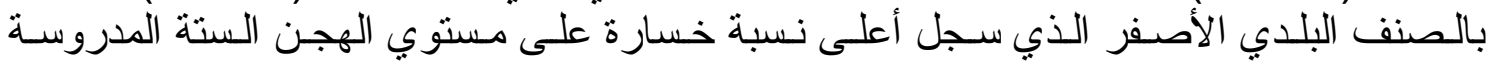

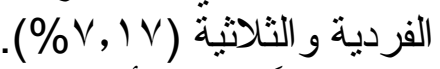

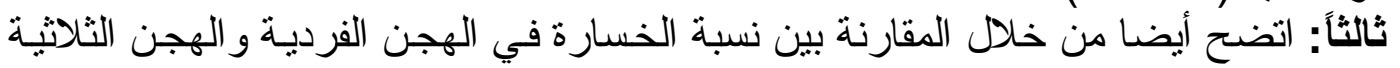
البيضاء:

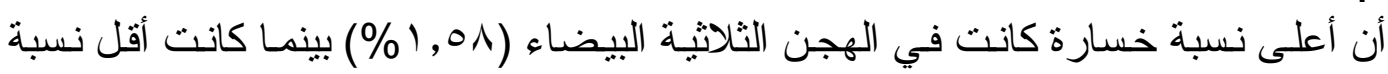

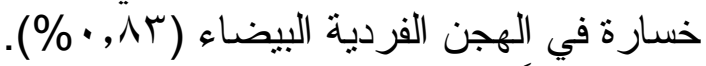

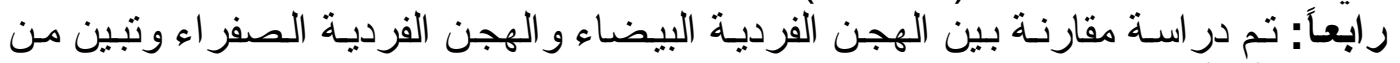

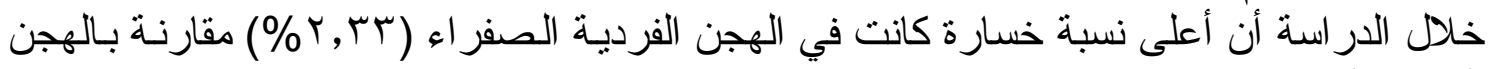

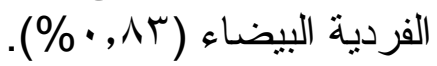

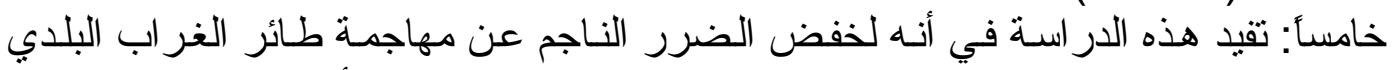

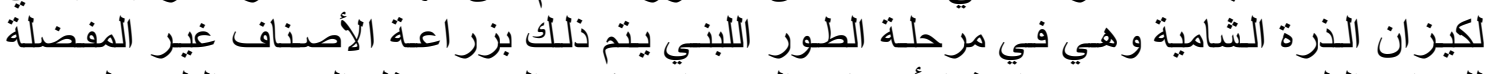

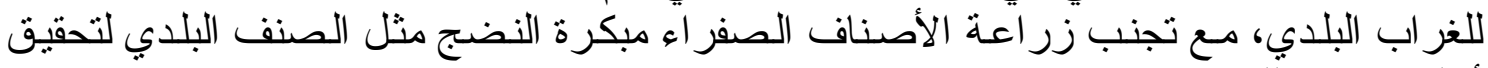

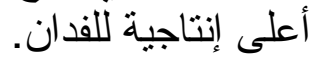

